\title{
FENOMENOLOGÍA DE LA VANGUARDIA: EL CASO DE LA NOVELA
}

\author{
Luis FERNÁNDEZ CIFUENTES \\ Harvard University
}

Quisiera comenzar por un descrédito y una justificación: las novelas españolas de vanguardia no son célebres ni son importantes; lo es, sin embargo, su visión del mundo y el contexto cultural que arropa esa visión. Sobre la novela española de vanguardia resulta iluminadora una comparación de tipo bibliográfico: entre los muchos trabajos dedicados al teatro español del siglo XX difícilmente se encontrará alguno que se ocupe específica y exclusivamente del "Teatro español de vanguardia"; existen, con todo, muchos trabajos sobre autores concretos u obras singulares que hoy se juzgan más o menos de vanguardia. El caso de la novela es exactamente el opuesto: predominan los trabajos sobre el grupo de novelistas llamado de vanguardia; los trabajos sobre autores u obras individuales son más escasos. Se diría, incluso, que separar sin más a estos autores o a sus obras constituye una suerte de falacia crítica: los unió, desde el principio, por una parte, el parentesco temático y formal de sus novelas y, por otra, todo su marco histórico-biográfico, desde la presencia de ese mentor casi dictatorial que fue Ortega y Gasset, hasta el carácter exclusivo y arrogante de sus tertulias y sus revistas (Revista de Occidente [1923] y Gaceta Literaria [1927] sobre todo) o su demarcación editorial (en las tres colecciones más destacadas que se crearon para publicar sus obras: "Nova Novorum", de la Editorial Revista de Occidente; "Nuevos Valores", de la Editorial Ulises, y "Cuadernos Literarios", de La Lectura). Los trabajos de historia literaria parecen esforzarse incluso, más o menos inadvertidamente, por purificar ese grupo, por eliminar de la nómina a todos aquellos autores o textos que resulten vacilantes o indecisos, es decir, que hagan algún tipo de concesiones. El consenso de críticos e historiadores no es completo, pero el denominador común es que en ese núcleo compacto y casi amurallado de novelistas no deben incluirse, en propiedad, más que Pedro Salinas (1892-1952), con Víspera del gozo (1926) "posiblemente la mejor obra de ficción del nuevo movimiento llamado arte joven" [Spires, 1988, pág. 130]; Benjamín Jarnés (1888-1949), 
con El profesor inútil (1926 y 1934), Paula y Paulita (1929) y, sobre todo, Locura y muerte de nadie (1929), "sin duda la mejor novela de Jarnés" [Ferreras, 1988, pág. 112] y "típica pieza de ficción vanguardista" [Pérez Firmat, 1982, pág. 126]; Antonio Espina (1898-1972), "la figura más representativa de la 'escuela" " [Nora, 1970, pág. 197], con Pájaro Pinto (1927) y Luna de copas (1929); Francisco Ayala (1906- ), "con Jarnés, el más importante narrador del grupo" [Nora, 1970, pág. 196], sobre todo por los dos relatos de Cazador en el alba (1930); y, si acaso, también Ernesto Giménez Caballero (1898-1981), con Yo, inspector de alcantarillas (1928) y Julepe de menta (1929). En los aledaños, siempre contaminados y discutibles, estarían otra docena de autores como Rosa Chacel, Max Aub, Juan Chabás... etc. Se impone ya, entonces, una primera conclusión: la novela española de vanguardia - como, de hecho, la vanguardia en general- se distingue por ese carácter compacto, elitista, exclusivo, al que los críticos e historiadores — desde Ortega en adelante- han apoyado no sólo con una puntual constatación sino también con una complicidad más o menos encubierta. El concepto de "teatro español de vanguardia", sin embargo, resulta inmediatamente sospechoso porque no cuenta, en principio, con ese carácter compacto y exclusivo de grupo uniforme.

Ahora bien, junto a ese fenómeno, la comparación bibliográfica conduce a otra conclusión significativa: en el teatro de la época es fácil reconocer obras aisladas de gran envergadura que han pasado al canon fundamental de la literatura española del siglo XX y que pueden competir en radicalismo y en calidad con lo mejor del teatro de vanguardia extranjero (Así que pasen cinco años [1931], El Público [1930-1936] o Tres sombreros de copa [1932]); lo que es más, se diría que buena parte de los estudios de obras y autores sueltos tienen por objeto probar su mérito singular y su derecho a ser incluidos en ese canón (es común, por ejemplo, en los estudios del teatro de Jacinto Grau y de Gómez de la Serna). El caso de la novela es, de nuevo, el opuesto: todo este episodio tan pulcro y ordenado de la narrativa española no ocupa más que un capítulo menor, la letra pequeña de la historia de la novela contemporánea. $\mathrm{Ni}$ la cantidad, ni la calidad, ni la trascendencia de esos textos han sido hasta ahora suficientes para alcanzarles individualmente un puesto de importancia en las historias de la literatura y, menos aún, en el canon oficial. Un solo ejemplo: en el volumen 7 de Historia y crítica de la literatura española 1914-1939, preparado por Víctor García de la Concha en 1984, entre casi mil páginas de estudios, esos cuatro novelistas merecen en total 17 páginas de atención, mientras dos de sus contemporáneos algo más canónicos -Miró y Pérez de Ayala- reciben, en conjunto, 62 páginas. Más aún, los que estudian al grupo de vanguardia se apresuran a señalar, por una parte, la deserción temprana de todos ellos, que, desde 1930, dejaron de escribir novelas o pasaron a escribirlas de otro modo; y, por otra parte, el carácter indeciso o insuficiente de su vanguardismo, incluso dentro del círculo más restringido. Por ejemplo, Eugenio de Nora [1970, pág. 230] emplea a menudo el término "vacilante" para referirse al compromiso vanguardista de estos autores; Pérez Firmat [1982, pp. 113-117 y 127] encuentra como rasgo común una "incertidumbre del autor ante sus materiales" e 
incluso una "incompetencia narrativa"; más recientemente, Andrés Soria [1988, pág. 21], en términos generales pero decididamente aplicables a este grupo, observa que "movimientos que en Europa se alzan contra el pensamiento burgués, en España llegan a un cierto diálogo con él".

Sin embargo, todas estas novelas de vanguardia, que apenas destacan por sí mismas, tienen en conjunto un interés excepcional que comparten con el mejor teatro vanguardista: me refiero al tipo de cuestionamientos y de problemas literarios o filosóficos que plantean a la historia de la literatura. Ya en 1924 había declarado Ortega [1981 a, pp. 25-26], con un gesto más temperamental que razonable: "Las diferencias particulares del arte joven me interesan mediocremente, y salvando algunas excepciones, me interesa todavía menos cada obra en singular [...]. Lo importante es que existe en el mundo el hecho indubitable de una nueva sensibilidad estética [...]. Ésto es lo que parece de algún interés definir". Ahora sabemos que no sólo "parece de algún interés" sino más bien de extraordinario interés. ¿Por qué? La razón podría rastrearse también en conocidos ensayos de Ortega, pero la formula de una vez Guillermo Carnero en un trabajo reciente [1989, pág. 85], cuando concluye: "Es sin duda la primera vez en la historia de Occidente que no estamos ante el habitual enfrentamiento generacional en materia de sustitución de principios o valores dentro de una macrotrayectoria histórica asumida, sino ante un proyecto de ruptura de la continuidad histórica".

La cuestión es, entonces: ¿en qué consiste, dentro de la narrativa, esa "ruptura de la continuidad histórica" que parece ser lo más interesante o lo más trascendente de su proyecto vanguardista? Si hasta ahora he seguido, con más o menos fidelidad, los presupuesto de Ortega sobre el tema, a partir de este punto debo comenzar a diferir. Ortega opina que el arte nuevo está hecho casi totalmente "de puras negaciones". Yo quisiera prestar más atención a los principios que postula y que trata de poner en práctica. Con todo, no cabe duda de que esos principios suponen inicialmente una negación, una ruptura o, mejor aún, una denuncia de los modos precedentes. Ahora bien, Ortega es equívoco al definir esa negación o esa denuncia: se refiere, por una parte, a la dicotomía realidad/irrealidad [1981a, pp. 28 y 41], es decir, los predecesores, todos los predecesores, pero sobre todo los más inmediatos, como Galdós, la mayoría de la generación del 98 y sus epígonos, serían realistas, mientras los autores de vanguardia denunciarían el agotamiento de aquel realismo y optarían por la representación de lo irreal. El tiempo y el pensamiento crítico han puesto en evidencia que esa oposición es, en el mejor de los casos, superficial, y no da cuenta, ni siquiera parcialmente, del verdadero problema. Pero Ortega propone, al mismo tiempo y un poco de paso, sin muchas explicaciones, otra dicotomía mucho menos superficial que acaso contradice a la anterior: se trata de la distinción entre lo falso o falaz y lo genuino. El arte nuevo - dice"tiende [...] a eludir toda falsedad" [1981a, pág. 20]. Según esta dicotomía, resultaría que la vanguardia denuncia en los realistas no tanto su realismo como la falsedad de ese tipo de realismo. En esta denuncia resuena ya, claramente, 
todo el pensamiento científico y filosófico de la época, porque la falsedad del viejo "realismo" parece consistir — desde el punto de vista de la vanguardiaen una falacia fenomenológica: entienden que tanto la narrativa del 98 como la de Galdós o, para el caso, Balzac, asume que es posible una percepción objetiva y completa de la realidad y, al mismo tiempo, confía en el poder del lenguaje para representar esa percepción. El proyecto de La Comédie Humaine o de las Novelas Contemporáneas y los Episodios Nacionales de Galdós, con su repetición de personajes, transcripción de vidas enteras... etc., resultaría así la manifestación literaria de esa fenomenología. Pero también cualquier descripción fragmentaria de Azorín; por ejemplo, la que breve y parcialmente, con un lenguaje ordenado e implacable, presenta un pueblo castellano y un hidalgo que lo contempla melancólicamente desde su balcón: ese fragmento no era una muestra de la fragmentación general con que percibimos la realidad, sino todo lo contrario, una sinécdoque que supone la suficiencia de la parte para dar cuenta del todo, tanto sincrónica como diacrónicamente. En la descripción de Azorín, de su libro Castilla (1912) [1935, pp. 75-78-81], el autor resume en dos páginas 300 años de historia para volver repetidamente al mismo balcón castellano y encontrar siempre a un caballero idéntico que contempla un paisaje inalterable con parecida melancolía.

Contra esa falacia, los novelistas de vanguardia fundamentan su obra en una nueva fenomenología que no traiciona a la realidad ni confunde al lector. Esa fenomenología dictamina, en primer lugar, que la percepción del narrador es puramente fragmentada y dispersa, transitoria e insuficiente. Más aún, esa percepción no sólo es fragmentada y transitoria en sí misma, sino que resulta distinta, personal y, como diría Ortega, "intransferible" de uno a otro individuo, de modo que no cabe presentar el fragmento como representación de una realidad, sino más bien como muestra de la imposibilidad de representar una realidad completa o suficiente. Desde este punto de vista, se puede concluir que la misión o el propósito de los relatos más o menos vanguardistas ya no es presentar -o representar - una determinada realidad, sino más bien, una percepción limitada a esa realidad; mejor, una percepción de sus propios límites. Tal vez ninguno de aquellos novelistas lo ejecutó con mayor destreza que Pedro Salinas en Víspera del gozo [pág. 37]; por ejemplo, en este fragmento de fragmentos: "La calle, inmóvil, pero poseída con la marcha del coche de una actividad vertiginosa y teatral, empezó a desplegar formas, líneas, espacios multicolores y cambiantes, rotos, reanudados a cada instante, sin coherencia alguna y con idéntica rapidez y destreza con que muestra un prestímano los colorinescos objetos que le van a servir en su juego, más que para que el público los vea, con el malicioso propósito de que su rauda sucesión cree una imagen confusa y apta para cualquier engaño en la mirada del espectador".

La misma cita podría ilustrar también el segundo postulado importante en la nueva fenomenología (derivado, claro, del anterior): si la perecepción es fragmentada y dispersa y, además, mediatizada siempre por una personalidad singular consciente de sus límites, no sería justo o, más bien, sería una falsedad 
añadir a esa percepción una trascendencia moral, un valor establecido, una categoría de símbolo, cualquier cosa que remitiera a un orden exterior, superior y absoluto o común. En la descripción del campo que proponía Azorín, las formas percibidas y anotadas estaban al servicio de una ideología o de un sentimiento que se pretendía universal. El capítulo donde se encuentra termina así [1935, pág. 82]: “¡Eternidad, insondable eternidad del dolor! Progresará maravillosamente la especie humana; se realizarán las más fecundas transformaciones. Junto a un balcón [...], en una casa, siempre habrá un hombre con la cabeza, meditadora y triste, reclinada en la mano. No le podrán quitar el dolorido sentir". Esas nociones de eternidad y permanencia eran especialmente ajenas al pensamiento vanguardista. En la descripción del campo que propone, por ejemplo, Benjamín Jarnés en Paula y Paulita [pp. 68 y 51], ha desaparecido todo rastro de eternidad, de dolor y de meditación: conscientemente, el observador se limita a anotar los datos puramente formales que percibe de forma provisional en una serie de instantes, sin conexión alguna con otra cosa que no sea, si acaso, un cuadro de Juan Gris. El texto de Jarnés dice únicamente: "Hoy es día de rectificar cada minuto toda la coloración del aire. Primero se embadurna el cielo, a trechos, con todos los matices de la leche mixtificada. Luego, sobre fondo de añil crudo, desfila una procesión de grises. Una escala de sienas y morados, franjas malva y jacinto. Ocres, amarillos terrosos [...]. Ahora, este paisaje es sólo un capricho de Juan Gris".

El tercer postulado de esta nueva fenomenología es de orden más inmediatamente literario y es quizá el que más ha servido para caracterizar a las vanguardias: se trata de una general desconfianza del lenguaje, un descrédito general de las palabras como instrumentos para representar una verdad o una realidad exterior. Explícitamente lo enuncia así un personaje de El profesor inútil, de Jarnés [pág. 230]: "Sólo gozáis percibiendo la pobre música de la palabras, signos sonoros que el moho y el relente de tantas insufribles bibliotecas vino desafinando a to largo de los siglos". Más importantes son las manifestaciones implícitas, es decir, las consecuencias de ese postulado: como la percepción, el lenguaje ha dejado de ser mero instrumento de representación y se ha vuelto un objeto en sí mismo. Se juega con las palabras, con las frases hechas, con las expresiones que la literatura convencional había prodigado, y se pone de manifiesto su volubilidad, su insuficiencia, las quiebras semánticas que deshacen su poder. Un solo ejemplo de los muchos que se encuentran en los relatos de Antonio Espina: "Xelfa, formado, abrió en abanico la evocación de su vida africana, y empezó a abanicarse lentamente, ahuyentando los mosquitos del calor" [Pájaro Pinto, pág. 34]. Esta desconfianza del lenguaje es, claro está, un síntoma general de la modernidad tal como la caracterizó, un ejemplo, Heidegger [Vattimo, 1986, pp. 61-71], pero adquiere un matiz especial en la narrativa de vanguardia: ya no se trata de lamentar un deterioro o una impotencia, sino de aprovecharlo ingeniosamente. Quizá nada distingue tan positivamente a las vanguardias como esta restauración del ingenio, el mismo ingenio que Gracián había elogiado y catalogado en pleno barroco ("El arte moderno, ejemplo de arte ingenioso" [Marina, 1992, pp. 131-169]). Este ingenio que explota ale- 
gremente la debilidad de las palabras se convierte en una de la señas de identidad del yo vanguardista: el yo ubicuo que - contra la pregonada ausencia del narrador realista - mediatiza inevitablemente todos estos relatos; el yo cuya percepción de la realidad y de sí mismo es fragmentada y dispersa, hasta el punto de que no le permite trascendencia ninguna, ni ideológica ni sentimental; ese yo encuentra un punto de apoyo, una justificación de su presencia literaria, de su escritura, en el ingenio. El lugar que en la narrativa precedente estaba reservado a la vida interior de los personajes, a su relación más o menos conflictiva con el mundo exterior, es en estos textos coto del ingenio.

Cuando estas novelas fueron publicadas en los años 20 nada llamó tanto la atención — ni despertó tantas críticas - como la cantidad de metáforas que sus narradores se permitían. Ortega había dictaminado [1981a, pág. 38] que la metáfora era "el más radical instrumento de deshumanización", pero también había insistido [1981a, pág. 116] en que todo tipo de "reacción subjetiva ante el objeto - como es sin duda la metáfora- era posible sólo en la lírica; "en una novela o en una teoría es fatal". Azaña se burlaba en su diario del 13 de mayo de 1927: "En la Revista de Occidente han tenido en suspenso la publicación de una novela [de Juan Chabás] porque no había en ella "bastante número de metáforas’ ¡Oh Dios! ¡Cuando nos ponemos a ser tontos!”. Ya en 1934, cuando la narrativa de vanguardia estaba en plena decadencia, se recibió así en la prensa ( $L a$ Voz) la segunda edición de una de estas novelas: "El profesor inútil sucumbe hoy bajo el agobio de un sinnúmero de metáforas caducas, como sucumbió antaño a la boga de la iconomanía, del fanatismo por la imagen, Benjamín Jarnés, en el trance de escribirlo" [Fernández Cifuentes, 1982, pág. 341 ]. Estas críticas, que acaso eran justas, no ayudan, sin embargo a comprender dos fenómenos importantes. Primero, que las metáforas, la iconomanía, tenían su razón de ser en el contexto filosófico de la vanguardia; eran una forma de acusar y compensar las deficiencias de la percepción; eran una forma de aprovechar y poner, a la vez, de manifiesto las deficiencias del lenguaje. Segundo, estas metáforas tenían un carácter y una función muy distintos a los de las metáforas más tradicionales o convencionales. Cuando el narrador de Valle Inclán escribe en la Sonata de otoño [pp. 35 y 69] que unas manos "eran pálidas, nobles y descarnadas como las de un rey asceta" o que un abuelo era "alegre y picaresco como un libro de antiguos decires", lo primero que se observa es que esas metáforas, sus adjetivos... etc., están al servicio de un sentimiento o una ideología, y lo segundo, que suponen una extraordinaria confianza en el lenguaje como instrumento de precisión. Cuando Francisco Ayala escribe 20 años más tarde, en Cazador en el alba [pág. 51]: "Era una tarde tan fría que el viento arrancaba de los árboles aceradas hojas Gillette", ya no expone un sentimiento sino más bien ese ingenio que aprovecha la quiebra semántica de la palabra "hojas". El ingenio se revela así como el principal instrumento de mediación entre la realidad y el lector: ya nada se presenta subrayado por el sentimiento o la ideología, como en las fantasías de Valle Inclán, sino más bien neutralizado o reducido por las asociaciones del ingenio. Un ejemplo más: donde Valle Inclán había escrito: "la besé temblando, como si 
fuese a comulgar su vida" [Sonata de otoño, pág. 67], Antonio Espina propone: "¿Quién apaga los labios de carne de Gloria Swanson apretando contra sus encías el cepillo dentífrico del beso?" [Luna de copas, pág. 119]. El ingenio parece asociarse aquí con el mal gusto en una suerte de gesto protector contra los hábitos de la vieja literatura.

Los críticos recuerdan con frecuencia que el gran maestro del ingenio fue Gómez de la Serna y que quizá la manifestación más genuina de la prosa vanguardista en España - dentro de la fenomenología que aquí se describefue la "greguería"; es claro que la mayoría de las metáforas e imágenes que agobian los relatos de vanguardia podrían catalogarse como "greguerías". En cualquiera de los dos casos cabe añadir que el ingenio no fue sólo una forma de mediación sino también de protección: protección contra la trascendencia, contra el sentimentalismo, contra la gravedad que habían predominado en el realismo anterior. Al lector de las gueguerías de Gómez de la Serna le sorprenderá encontrar una enorme cantidad de ellas dedicadas a la muerte o donde la muerte tiene un papel excepcional; greguerías como la que asegura "La muerte es una enfermedad hereditaria"; o esta otra: "cuando recogemos un guante caído damos la mano a la muerte". Se diría que se convoca a la muerte precisamente para evitarla, para desfigurarla, para protegerse de ella con la burla del ingenio. Significativamente, los relatos de vanguardia están llenos de muertes y de suicidios que reciben el mismo tratamiento imaginístico o ingenioso. Antonio Espina describe así el suicidio de Aurelio en Luna de copas [pág. 154]: "Al lanzarse al espacio cruzó por su cerebro el mito de la Copa Encantada. Y lo fue desarrollando en el film de corto metraje que había de recorrer desde la altura de su inocente avión, hasta la superficie del Canal de la Mancha". Algunos críticos han pensado que la obra maestra o la más representativa de este grupo podría ser Locura y muerte de Nadie, de Benjamín Jarnés. "Nadie", que se llama Juan Sánchez, muere en la última página arrollado por un camión. La última frase de esa última página específica: "Como una goma de borrar".

Desde comienzos del siglo XX, - aparte de la fenomenología de Heidegger, que es su apoyo más evidente [Vattimo, 1988, pp. 18-42] - una serie de acontecimientos científicos, filosóficos y técnicos acompañaban y avalaban la nueva fenomenología. Ya a mediados del siglo XIX Baudelarie había escrito, de acuerdo con Poe: "No está lejos el tiempo en el que se comprenderá que toda literatura que se rehuse a marchar fraternalmente entre la ciencia y la filosofía es una literatura homicida y suicida" [Benjamín, 1972, pág. 58]. El primero de aquellos acontecimientos, el más acreditado y, a la vez, el más confuso fue la Teoría de la Relatividad. En España, Einstein había divulgado personalmente su teoría en Marzo de 1923, y una serie de libros pretendían hacerla accesible al público español, pero no era necesario que los artistas y los poetas entendieran las ecuaciones de Einstein; les bastó con la intuición o la certeza de que la percepción inmediata ya no era fidedigna, el mundo había dejado de ser transparente, el tiempo y el espacio habían perdido su valor absoluto y no toleraban ya una representación definitiva e inequívoca. El segundo, la teoría 
del inconsciente, fue explotado con menos cautela. En 1992 Ortega propuso a la Biblioteca Nueva la traducción de las Obras Completas de Freud, y en 1923 se leían ávidamente los primeros tomos. Poetas y artistas confirmaron allí que nuestro conocimiento de la realidad era a la vez condicionado y refundido por una lógica interior y estrictamente personal, ajena a la razón convencional y mucho más genuina que ella. La lógica externa, común, del realismo se reveló así no sólo falaz sino también represiva, una precaución contra el inconsciente individual, una forma de reducir o sofocar la imaginación propia. Entre los nuevos, este recién adquirido desprecio de la razón tradicional -escribe Guillermo Carnero [1989, pág. 95] - "supone la orientación de la capacidad y la energía cognoscitivas hacia la sensibilidad, el instinto, la intuición, la emoción [en el sentido, sobre todo, de excitación], términos que aparecen constantemente en los textos futuristas para expresar garantía de verdad ontológica y moral". Esa "verdad" del inconsciente justifica los dos sentidos de la originalidad tan cultivada por los vanguardistas: originalidad de lo originario, lo no reprimido, contaminado o reducido por las convenciones de la tradición (como, por ejemplo, el arte primitivo); originalidad de lo mío, lo singular, lo intransferible (como por ejemplo, los sueños, las fantasías, los delirios de la fiebre. Así, el narrador de Cazador en el alha [pág. 41] asegura: "Entonces comprendió el soldado Antonio Arenas que las realidades puras sólo son visibles a la temperatura de 40 grados centígrados"). El tercer fenómeno y, para algunos (Pérez Firmat, C.B. Morris) el que más determinó las nuevas formas narrativas, fue e! cinematógrafo: tanto su técnica como su estética (si cabe distinguirlas) parecían ajustarse a todos los hallazgos de la nueva fenomenología. Estaba, por una parte, la paradoja de la "cinta", que desglosaba toda ilusión de realidad, de continuidad, de movimiento, en una cadena de fragmentos inequívocamente fijos; estaba, por otra parte, la función creadora del "montaje", la posibilidad de cortar y unir todos esos framentos para producir las más insólitas yuxtaposiciones de tiempo y espacio; estaba, finalmente, el "movimiento" - -con las alternativas de cámara lenta y cámara rápida - como una acentuación de la evterioridad o la visualización que favorecía el nuevo arte.

Quisiera aquí, sin embargo, prestar especial atención a un coincidencia mucho menos estudiada: la que se produce, indudablemente, entre esta fenomenología que legitima los relatos de vanguardia y la modernización de las grandes ciudades. Ya Juan Cano Ballesta [1981, pág. 172] ha observado que "la gran empresa de la prosa vanguardista es plasmar en su sorprendente retórica la integración del hombre en la cosmópolis moderna". Pero, al mismo tiempo, esa "sorprendente retórica" es producto de la cosmópolis que condiciona o determina las percepciones del artista. El momento fundacional de ese modelo universal llamado cosmópolis o metrópolis puede localizarse con bastante exactitud entre 1852 y 1870 , cuando el alcalde de París, barón de Haussmann, arrasó los viejos barrios de la ciudad para instaurar la nueva geometria de los grandes bulevares, los parques de Boulogne y Vincennes y el enorme mercado de Les Halles. Para el resto de las ciudades europeas, ese gesto de Haussmann fue sobre todo simbólico: Cosmópolis no es el nuevo París 
sino una ciudad ubicua, equidistante a la vez de las ciudades particularizadas y costumbristas de la narrativa decimonónica, y del campo idealizado por la generación del 98. Madrid, Sevilla, Zaragoza son las ciudades aludidas por los narradores de vanguardia, pero las tres se caracterizan sobre todo por haber sacrificado su identidad ("el color local", diría un crítico de entonces) a su parentesco con Cosmópolis: las tres ofrecen en general el mismo espectáculo de "superficies inasibles, desnudas, cristalizadas, de glacial blindaje", que un personaje de Francisco Ayala encuentra inesperadamente en el Madrid de 1928 [Cazador en el alba, pág. 89].

Más importantes que esa geometría común del nuevo espacio urbano son otros tres datos de la cosmópolis vanguardista. El primero es su carácter de puro presente, sin pasado. "Pluscuampresente", lo llama Jarnés [El profesor inútil, pág. 119]. Cuando el protagonista de Cazador en el alba [pág. 48] llega a la ciudad, el narrador especifica: "anulado el pretérito, había renacido en el centro del trajín urbano". Cosmópolis no tiene pasado y cancela el de sus habitantes: "sólo contaban con su efectiva presencia; no tenían pasado y el porvenir estaba en sus manos, sumiso"; "lo presente, lo inmediato, ocupaba toda su atención" [Cazador en el alba, pp. 54 y 69]. En Erika ante el invierno el periódico se convierte en emblema de ese insobornable presente: un periódico atrasado es un objeto inútil, insignificante, para el ciudadano ("la tarde de ayer... ¿Cuándo había sido la tarde de ayer? ¿De qué ayer sin nombre?", [pág. 80]). Relacionado con ese presente, el segundo dato de Cosmópolis es la mutación constante, el flujo inagotable de las gentes, las imágenes, los acontecimientos. Jarnés lo compara con un río y sus puentes: "Io único firme es el agua. Los puentes se están siempre desmoronando, a la fuerza de querer detenerlos sobre la vida" $\mid E t$ profesor inútil, pág. 119]. Lo fijo pertenece al pasado y no tiene ninguna función en Cosmópolis. El personaje de Salinas que espera a su novia en la calle se encuentra así con que "la figura inventada y esperada se venía abajo de un golpe, porque Jorge la había labrado con lo conocido, con los datos de ayer, con el pasado. Y lo que tenía delante [...] era la vida de hoy"; "Formas, líneas, colores de todas clases le salían al paso copiosamente" [Víspera del gozo, pp. 101 y 94]. Francisco Ayala resume, con el estilo que le impone esa misma movilidad de Cosmópolis: "Estación. Pista. Fábrica. Velódromo. Universidad. Circo. Gimnasio. Cine. La ciudad, gran plataforma giratoria" [Cazador en el alba, pág. 94]. El tercer dato de Cosmópolis es una forma de negación: el campo ha sido reducido a un espectáculo rápido y ajeno que se contempla un momento por la ventanilla del tren o del coche, los vehículos que trasladan al ciudadano de una a otra cosmópolis. Más aún, ya no importa el paisaje en sí, sólo anotar, como hace Salinas, "las compañías fugaces y alusivas de los paisajes laterales" [Víspera del gozo, pág. 76]; Francisco Ayala lo dice así [Cazador en el alba, pág. 46]: "dos cintas de paisaje habían desfilado a derecha e izquierda". El que más explicítamente ha teorizado sobre esta exclusión es seguramente Giménez Caballero, que opone la "visión estática" de los del 98, a la visión dinámicá, "del coche en directa" de los vanguardistas. De los pueblos le interesa más la gasolinera que la vieja iglesia románica. Su mismo estilo cancela las prerroga- 
tivas del campo con un lenguaje puramente urbano. Escribe, por ejemplo: "comenzamos a transitar por los pueblos castellanos higiénicamente enrollados por esa cinta cinemática que es la carretara; englobados en la esfera, vertiginosa de humo, de la gasolina" [Julepe de menta, pp. 59-61].

A comienzos de los años 30, Walter Benjamin — sin duda inspirado o incluso determinado por el espíritu de las vanguardias - analizó lo que había supuesto París, como gran ciudad, para la literatura del siglo XIX (Baudelaire, sobre todo). En aquel París de los grandes bulevares y los pasajes comerciales encontró Benjamin dos figuras decisivas: por una parte, la multitud, "una multitud inabarcable en la que nadie está del todo claro para el otro y nadie es para otro enteramente impenetrable" [1972, pág. 64]; por otra parte, observando a la multitud, "abandonado en la multitud" [pág. 71], pero no mezclado con la masa, sino más bien separado de ella por un umbral que nunca traspasa del todo, se encuentra el "flâneur". Significativamente, Benjamín nunca da de una vez por todas la definición de este paseante escurridizo, este héroe incógnito [pág. 55], a la vez ingenioso y negligente [pág. 56], que "va a hacer botánica al asfalto [porque] la vida sólo medra en toda su multiplicidad, en la riqueza inagotable de sus variaciones, entre los adoquines grises" [pág. 51]. Una variante de este "flâneur" da lugar al protagonista esencial de los relatos de vanguardia; la fenomenología urbana del "flâneur" es, a la vez, la que domina esos relatos.

La primera de sus características o la que conviene precisar con más urgencia es su asociación con los exteriores, la calle, el bulevar: "El bulevar es la vivienda del flâneur", anota Benjamin [pág. 51]. En los relatos del realismo tradicional, la calle era fundamentalmente un lugar de tránsito o de enajenación: se podría analizar en profundidad todo Fortunata y Jacinta a través de esta única disyuntiva entre interiores y exteriores. Los relatos de vanguardia, en cambio, son generados y sostenidos por esta precipitación del flâneur hacia el exterior, lejos de la quietud y la fijeza, del orden previsto y la repetición. De todos sus protagonistas se puede predicar lo que Ayala de los suyos en Cazador en el alba lpág. 60]: "buscaban las grandes avenidas. Las calles más abiertas, por donde huían, persiguiéndose de esquina en esquina, los anuncios luminosos". El flâneur sólo desea, en palabras de Ayala, "echarse a la calle, alegre nadador del aire libre". "Y salí a la calle. Decidido. Precipitado. Lleno de Aire. Viaducto. Lanzaderas. Gente. Más gente. En medio, mi apresuramiento" [Ibid, pp. 64 y 99]. Cuando "el profesor inútil" de Jarnes [pág. 215], al final de una aventura, tiene que entrar a la vivienda de su amada, declara: "el gabinete era un acuario. Entré en él como descienden los buzos al fondo del mar. Temía perder el contacto con el aire exterior, y hubiera preferido respirar por un tubo de comunicación con la calle".

Pero la calle no es sólo el inquieto habitat del flâneur: la calle, lo callejero, su atmósfera, su vocabulario, abastecen todo el imaginario del flâneur; los demás espacios de su historia se definen en términos de oposición o de afinidad con la calle. Así se desacreditan alcobas y gabinetes y brillan generalmente por 
su ausencia toda clase de espacios íntimos, mientras adquieren su prestigio los mercados - "catedrales del color" las llama "el profesor inútil" [pág. 82] - o el museo - "un silencioso mercado" [ibid, pág. 85]—. El flâneur de Salinas expone así esa reciprocidad o esa equivalencia: "Llevábamos ocho días de recorrer por único campo las asfaltadas praderas de la ciudad, y sólo nos reposaban las luminosas sombras de las farolas, con su maravilloso follaje nocturno. Y como sentías nostalgía del suelo y los chopos de Castilla, te llevé al Museo" [Víspera del gozo, pág. 80]. La proliferación de trenes en estos relatos se debe, en parte, al parentesco que mantienen con las calles: la última protagonista de Víspera del gozo [pág. 148], al despedirse en la estación, "ya trae puesta la cara de viaje, un rostro impersonal y anónimo a propósito para circular unas horas entre esas gentes compañeras y desconocidas que vayan en el tren" [subrayado mío]. Por esa misma razón, ningún interior se vuelve más tolerable que el interior de los hoteles, con su carácter provisional y su población de transeúntes desconocidos; o esos grandes restaurantes que Jarnés describe así: "El comedor es un abigarrado mecanismo, una divertida máquina social donde cada pieza acusa un taller de construcción distinto" [Paula y Paulita, pág. 44].

¿Y qué hace el flâneur en la calle? ¿Cuál es su función, su misión? Desde luego no es el trabajo, que en estos relatos es apenas un espectáculo, como en Ayala, un inconveniente apenas atendido, como en Jarnés, o una perfecta ausencia, como en Salinas. Pero tampoco es el ocio. Habría que nombrarlo algo así como una laboriosa desocupación. Francisco Ayala dice de su flâneur: "El era el desocupado que se para ante los rascacielos, viendo cómo chorrea el sol por sus aristas hasta regar las anchas avenidas; que se detiene a contemplar la agitación de talleres y estaciones" [Cazador en el alba, pág. 67]; Benjamin Jarnés lo nombra "consumado catador de vivas plasticidades" [Locura y muerte de Nadie, pág. 45]. En ambos casos se alude a una constante atención a lo que pasa, casi un registro de las variedades urbanas ("entomólogo" es el "flâneur" de Francisco Ayala [pág. 59], como había sido "botánico" el de Benjamin). La pesquisa descubre incluso una suerte de subsconsciente urbano. El título más significativo de Giménez Caballero no deja lugar a dudas: Yo, inspector de alcantarillas. Benjamin considera que el flâneur "legitima su paseo ocioso" mediante una labor de detective [pág. 55]; en estos textos se alude al protagonista como "pescador [...] en la ciudad, entre los hombres" [Luna de copas, pág. 123]; "minero de espíritus, de socavar estrato por estrato, las entrañas de un nuevo continente" [Locura y muerte de Nadie, pp. 32-33] y, sobre todo, "cazador": "cazador en el alba" o "cazador de sucesos" para el que "la más rica aventura" es salir "a caza de sí mismo" [El profesor inútil, pág. 57]. En todo caso, se trata de una forma de conocimiento difícilmente definible porque no tiene límites ni prescripciones; apenas si la caracteriza una vaga ansiedad de exponerse a todas las experiencias posibles, sin agotar ninguna: "fertilizar cada hora con un nuevo afán, con una idea nueva", dice el protagonista de Paula y Paulita [pág. 213]. "El profesor inútil", aspira a "vivir aguardando estímulos, sin normas previas rubricadas por ningún Anciano"; quiere ser "el hombre que 
siente llegar todas las flechas, y, en una encrucijada, elige todos los caminos" [pág. 58].

Indirectamente, todas estas posibilidades aluden a la multitud donde explora el flâneur en busca de fragmentos con los que construir ingeniosamente otra realidad. Ahora bien, de ese flâneur se puede postular lo que Ortega predicó sobre los artistas de vanguardia: sabe exactamente lo que no quiere, lo que debe evitar (todo compromiso definitivo; todo lo agotador, lo heredado, lo establecido de una vez por todas: "no puedo con las preocupaciones, las ideas fijas, signos de indecorosa debilidad"; "las ideas falsas, capciosas, multitudinarias o en estado de putrefacción", escribe Antonio Espina en Luna de copas [pp. 34 y 106]; el flâneur de Locura y muerte de nadie [pág. 59] aparece en su mejor momento "sin opiniones, sin prejuicios, sin pasado y sin futuro, con un fugaz y encantador presente"; "Yo ni blasfemo ni rezo: contemplo", dice "el profesor inútil" [pág. 103]). Pero no tiene una idea segura de lo que busca o lo que aspira a construir: en su indagación juega un papel decisivo la casualidad, el azar, el capricho: "me entregaré al azar, gentil dominador del mundo", declara el protagonista de Paula y Paulita [pág. 34]; "No puedo trabajar", exclama el de El profesor inútil; se lo impide "este afán de salir al encuentro del azar" [pág. 45]; y abandona la enseñanza para sentarse en un bar "esperando ser grato a la casualidad, buena amiga y maestra de todos los investigadores" [ibid, pág. 27]. Más aún, ese azar no es ninguna noción abstracta, sino más bien la pura naturaleza de la ciudad, y así concluye Salinas [Víspera del gozo, pág. 41]: "No iba el hombre en ningún momento allí donde su propósito lo impulsara, sino donde el capricho de la ciudad, su alma voluntariosa e indómita, le atrajera".

La herramienta fundamental para este indagador de exteriores no es la palabra sino la mirada: el lector más superficial podría observar inmediatamente que estos textos, casi siempre breves, se diferencian de los largos relatos realistas por la escasez del diálogo. En los interiores de Galdós se hablaba incesantemente y el diálogo determinaba el curso del relato. El flâneur que callejea no tiene urgencia ni acaso deseo de hablar con nadie, no confía en unas palabras casi siempre previsibles que, en el mejor de los casos, no conducen a nada y, en el peor, son puro encadenamiento de lugares comunes. "No creo en el diálogo", dice sencillamente el flâneur de Paula y Paulita [pág. 56]. "El profesor inútil" [pág. 159] declara: "prefiero que la charla de Carlota no tenga ningún sentido, que sus frases estén elaboradas con sonidos puros, donde yo pueda estudiar, - como en el aula - la intensidad, el tono y el timbre". Antonio Espina ridiculiza sus escasos diálogos con acotaciones teatrales o con el título: "Diálogo". Al flâneur de las vanguardias, más que las palabras le interesan los gestos del interlocutor que capta con la mirada. El "Inspector de alcantarillas" [pág. 73] observa: "En general, no era lo que contaba - lo estremecedor-, sino el guiño oportuno de un párpado [...], aquella economía fácil de sus gestos, y aquella administración perfecta de sus facciones". Por la misma razón, casi las únicas palabras que atraen al flâneur son las de los grandes carteles que inundan las cosmópolis de estos relatos. Pedro Salinas se refiere a 
ellas como "esa poesía estricta y sorprendente del anuncio luminoso" (pág. 143). Con todo, lo que ostentosamente suplanta $-\mathrm{y}$, en definitiva, humilla-al diálogo, a la voz, a la comunicación verbal, son los múltiples ruidos urbanos, "la formidable ópera de la calle: gritos, claxons, timbrazos de tranvía y parpadeo de los escaparates", como escribe Francisco Ayala [Cazador en el alba, pag. 95]. En esa "ópera", el automóvil que multiplica las experiencias visuales del flâneur, es para Antonio Espina, una "caja de música, con Beethoven en el motor - andante maestoso-y Stravinski en los saltos de ballestaje" [Pájaro Pinto, pág. 60]; de uno de esos claxons Ilegará a escribir Pedro Salinas [Víspera del gozo, pág. 46] que "lanzó un rugido plañidero y bronco [...] en el que se reconocía, muy clara, hoy y empapada de siglos, la desesperación impotente y grandiosa con que el burlado egipán ve cómo se le escapa de nuevo la ninfa esquiva y deseada".

Pero todo ese ruido no es más que un cómplice o un apoyo de la mirada: “yo, sentado en medio de la turbia orquesta, dejo vagar mis ojos en torno", declara "el profesor inútil" [pág. 72]. Benjamin [1972, pág. 52] cita a Simmel: "He aquí algo característico para la sociología de la gran ciudad. Las relaciones alternantes de los hombres en las grandes ciudades... se distinguen por una preponderancia expresa de la actividad de los ojos sobre la del oído". Antonio Espina, explorador ya en esa gran ciudad, asegura: "El oído no fue nunca un sentido directriz. El ojo, sí" [Pájaro Pinto, pág. 32]. Y Jarnés especifica: "Son los ojos espías vivaces de la voluptosidad, de la que suelen consumir la porción más rica, dejando a los otros sentidos el despojo" [Locura y muerte de Nadie, pág. 145]. Francisco Ayala es menos explícito, pero sus relatos ponen de manifiesto todo el poder y la prioridad de la mirada, por ejemplo en este pasaje de Cazador en el alba [pp. 55-56], donde apenas hay ningún intercambio verbal: "Entre ella y su hermano repartía Antonio miradas equitativas [...]. Antonio, por su parte, se sentía mirado - medido - de hombro a hombro [...]. Antonio había ingresado de un golpe en un mundo de pequeños latidos, de oscilaciones, de amnesias, de lúcidos despertares". De hecho, como en esta cita, el flâneur de los otros relatos es casi siempre una figura masculina cuya mirada está gobernada por el erotismo: lo que busca en la multitud urbana es, en definitiva, lo que llama Salinas "fragmentos de su amor completo", con los que aspira a construir el "puzle" de su fantasía; literalmente, un sombrero, una postura, un descote, el color de una blusa... Ya Benjamin [1972, pág. 61] había descrito la relación erótica del flâneur con esa multitud que, en los versos de Baudelaire, es el "asilo del amor que se le escapa al poeta". Ahora, para la mirada del flâneur de vanguardia, la mujer y la multitud, la mujer y la ciudad aparecen enteramente identificadas, como en esta comparación de Salinas: "La avenida corta y voluptosa, toda florida de acacias, como esa mirada con que una mujer o una ciudad nos invita a seguirla, a ir más allá" [Víspera del gozo, pâg. 26].

Y ¿cómo termina esta azarosa indagación del flâneur?; o, en otras palabras, ¿cómo se cierran estos relatos de vanguardia? De hecho, no se cierran: la multitud - "fisionomías nuevas e iguales siempre", como observa paradójica- 
mente un personaje de Francisco Ayala [Cazador en el alba, pág. 73] — es la biblioteca del flâneur, la fuente de sus aventuras cognoscitivas y amorosas, pero es también, con igual puntualidad, la causa de su decepción y de su fracaso. Los éxitos del paseante, anota Jarnés, son "efímeros, banales"; en general, no encuentra en la multitud más que "seres intermedios, normales, caras y cuerpos de desesperante equilibrio. Un mismo maniquí ha servido para treinta gabanes; igual módulo para cien fisionomías; idéntico manual para todos los saludos" [Locura y muerte de Nadie, pág. 24]. La ciudad y la mujer no se rinden nunca del todo al ingenio del flâneur, y Salinas debe concluir: "la ciudad le era, tan dentro de ella, algo incierto e inaprehensible como una mujer amada" [Víspera del gozo, pág. 44]. Tampoco sería injusto concluir que estos relatos, como casi todos los de la historia de literatura, cuentan sólo fracasadas historias de amor. La diferencia está en la forma del fracaso, en su textura fenomenológica y en el hecho de que no constituye una situación final, definitiva; sólo el punto de partida para una nueva acometida del ingenio. La condena del flâneur es la constante movilidad, no poder deternerse nunca. Salinas lo ha expresado así: "Imposible estarse quieto aquí, en estas calles onduladas y penetrantes como frases nocturnas. Pero imposible, luego, ir a parte alguna, servirse de aquellos viales para el logro de un designio [...]. Había que [...] marchar sin adonde, querer ir, pero sin ninguna llegada" [Víspera del gozo, pág. 41]. Ingeniosamente, Benjamín Jarnés [El profesor inútil, pág. 251] y Pedro Salinas [Víspera del gozo, pág. 125] coinciden en señalar que la biografía del flâneur no está escrita "en el libro enorme y tan difícil de consultar del destino, sino en una guía de ferrocarriles".

\section{OBRAS CITADAS}

AYALA, Francisco. 1971. Cazador en el alba y otras imaginaciones, Barcelona, Seix Barral.

BENJAMIN, Walter. 1972. Iluminaciones / 2 (Baudelaire), Madrid, Taurus.

CANO BALLESTA, Juan. 1981. Literatura y tecnología. Las letras españolas ante la revolución industrial (1900-1933), Madrid, Orígenes.

CARNERO, Guillermo. 1989. Las armas abisinias. Ensayos sobre literatura y arte del siglo XX, Barcelona, Anthropos.

ESPINA, Antonio. 1927. Pájaro Pinto, Madrid, Revista de Occidente.

-1929. Luna de Copas, Madrid, Revista de Occidente.

FERNÁNDEZ CIFUENTES, Luis. 1982. Teoría y mercado de la novela en España, Madrid, Gredos.

FERRERAS, Juan Ignacio. 1988. La novela en el siglo XX (hasta 1939), Madrid, Taurus.

GARCÍA DE LA CONCHA, Víctor (coord.). 1984. Historia y crítica de la literatura española, vol. VII, Época contemporánea, 1914-1939, Barcelona, Crítica.

GIMÉNEZ CABALLERO, Ernesto. 1929. Julepe de menta, Madrid, Cuadernos Literarios.

- 1975. Yo, inspector de alcantarillas, Madrid, Turner. 
JARNÉS, Benjamín. 1927. Paula y Paulita, Madrid, Revista de Occidente.

- 1929. Locura y muerte de Nadie, Madrid, Ediciones Oriente.

- 1934. El profesor inútil, Madrid, Espasa-Calpe.

MARINA, José Antonio. 1992. Elogio y refutación del ingenio, Barcelona, Anagrama. MARTÍNEZ RUIZ, José “Azorín”. 1935. Castilla, Madrid, Biblioteca Nueva.

MORRIS, C.B. 1980. This Loving Darkness. The Cinema and Spanish Writers, 19201936, Oxford, Oxford University Press.

NORA, Eugenio de. 1970. La novela española contemporánea, II, Madrid, Gredos.

ORTEGA Y GASSET, José. 1981 a. La deshumanización del arte, Madrid, Alianza.

- 1981 b. Ideas sobre el teatro y la novela, Madrid, Alianza.

PÉREZ FIRMAT, Gustavo. 1982. Idle Fictions. The Hispanic Vanguard Novel, 19261934, Durham, Duke University Press.

SALINAS, Pedro. 1926. Víspera del gozo, Madrid, Revista de Occidente.

SORIA OLMEDO, Andrés. 1988. Vanguardismo y crítica literaria en España, Madrid, Istmo.

SPIRES, Robert. 1988. Transparent Simulacra. Spanish Fiction 1902-I926, Columbia, The University of Missouri Press.

VALLE INCLÁN, Ramón María del. 1988. Sonata de Otoño, Madrid, Espasa-Calpe.

VATTIMO, Gianni. 1986. El fin de la modernidad, Barcelona, Gedisa.

- 1988. "Dialéctica, diferencia y pensamiento débil", en Vattimo, Gianni y Rovatti, Pier Aldo, eds., El pensamiento débil, Madrid, Cátedra. 